\title{
PEMUPUKAN DOSIS KALIUM TINGGI \\ UNTUK MENINGKATKAN BOBOT PIPILAN KERING JAGUNG DI LAHAN KERING JAWA TIMUR
}

\section{HIGH POTASSIUM DOSAGE TO INCREASE WEIGHT OF DRY SHELLED CORN AT DRYLAND IN EAST JAVA}

\author{
Listy Anggraeni $^{1)}$, Riza Ulil Fitria ${ }^{1)}$ dan Nurul Istiqomah ${ }^{1)}$ \\ ${ }^{1)}$ Balai Pengkajian Teknologi Pertanian (BPTP) East Java \\ Email: listyanggraeni0@gmail.com
}

\begin{abstract}
ABSTRAK
Lahan kering di dataran rendah mempunyai iklim kering, sehingga curah hujan rendah, ketersediaan air sangat terbatas, evaporasi dan transpirasi tinggi. Akibatnya tingkat kesuburan tanah rendah. Peningkatan hasil pipilan kering jagung tergantung pada masukan pupuk $\mathrm{N}$ dan $\mathrm{P}$ anorganik yang tinggi, tetapi hal ini tidak efisien dan menyebabkan ketidakseimbangan NPK pada tanah. Pupuk kalium berfungsi meningkatkan pertumbuhan dan hasil panen pipilan kering pada kondisi stres kelembaban di iklim kering. Penelitian dilakukan untuk mendapatkan kombinasi pupuk NPK dengan kalium dosis tinggi dan urea yang tepat untuk meningkatkan bobot pipilan kering jagung. Penelitian dilakukan di Desa Pakong, Kecamatan Pakong, Kabupaten Pamekasan, menggunakan pupuk NPK 1510-19. Rancangan Acak Kelompok dengan 10 perlakuan dan 3 ulangan. Peubah yang diamati adalah tinggi tanaman, jumlah daun, panjang dan diameter tongkol, bobot 100 butir dan hasil jagung pipilan kering. Data dianalisis dengan ANOVA (Analisys of Variance) dilanjutkan DMRT pada $\alpha=5 \%$ dan analisis finansial menggunakan $\mathrm{R} / \mathrm{C}$ ratio. Hasil penelitian menunjukkan bahwa pupuk NPK 15-10-19 berpengaruh nyata terhadap tinggi tanaman, panjang dan diameter tongkol, bobot 100 butir dan hasil jagung pipilan kering. Perlakuan pupuk $350 \mathrm{~kg} \mathrm{ha}^{-1}$ Urea $+250 \mathrm{~kg} \mathrm{ha}^{-1} \mathrm{NPK} 15-10-19$ memberikan nilai $\mathrm{R} / \mathrm{C}$ rasio yang lebih tinggi daripada perlakuan lainnya yaitu sebesar 2.14. Pupuk NPK 15-10-19 sebanyak $250 \mathrm{~kg} \mathrm{ha}^{-1}$ + Urea $350 \mathrm{~kg} \mathrm{ha}^{-1}$ merupakan usahatani yang paling menguntungkan dan mampu meningkatkan hasil jagung pipilan kering hingga $7.3 \mathrm{t} \mathrm{ha}^{-1}$.
\end{abstract}

Kata kunci: iklim kering; jagung pipilan kering; kalium; lahan kering; NPK

\begin{abstract}
Dry-lowland has a dry climate, so rainfall is low, water availability is very limited, high evaporation and transpiration. That resulted in low fertility of soil. The increase in yield of dry shelled corn depend on high input of fertilizer $N$ and $P$ inorganic, but this way is not efficient and leads to an imbalance of NPK in soil. Potassium fertilizer works to increase the growth and yields of dry shelled on the stress conditions of moisture in dry climate. This research conducted to get a combination of NPK fertilizer with high dose of potassium and urea to increase the weight of dry shelled corn. Research conducted in the Village of Pakong sub-District Pakong, Pamekasan, using NPK fertilizer 15-10-19. A Randomized block is designed with 10 treatments and 3 replications. Variables observed
\end{abstract}


were plant height, number of leaves, length and diameter of cob, weight of 100 grains and yield of dry shelled corn. Data was analyzed with ANOVA (Analysis of Variance) followed by DMRT at $\alpha=5 \%$, and financial was analized using $R / C$ ratio. The results showed that NPK fertilizer gave significant effect on plant height, length and diameter of cob, weight of 100 grains and yield of dry shelled corn. Treatment of $350 \mathrm{~kg} \mathrm{ha-1} \mathrm{Urea}+250 \mathrm{~kg} \mathrm{ha-1}$ NPK 15-10-19 gave higher $R / C$ ratio than other treatment, which was 2.14. Application of

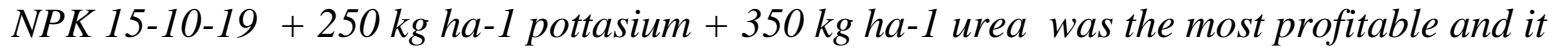
increased the yield of shelled corn dried up to 7.3 tha-1.

Keywords: dry climate; dry-lowland; NPK; dry shelled corn; potassium

\section{PENDAHULUAN}

Dalam rangka mendukung program pengembangan agribisnis jagung diperlukan kajian pemupukan NPK. Unsur hara $\mathrm{N}$, P, dan $\mathrm{K}$ merupakan unsur hara makro esensial untuk pertumbuhan dan hasil panen jagung (Tabri, 2010). Sebagian petani hanya menggunakan pupuk Urea atau kombinasi Urea + ZA, sementara lahan usahatani jagung selain kahat $\mathrm{N}$ diduga juga kahat $\mathrm{P}$ dan $\mathrm{K}$. Oleh karena itu perlu dilakukan pemupukan dengan $\mathrm{P}$ dan $\mathrm{K}$ untuk meningkatkan produksi jagung (Tandisau, et al., 2016).

Hasil jagung dapat ditingkatkan dengan pemupukan yang tepat, baik dosis dan waktu maupun jenis pupuk yang diberikan (Damanik et al., 2010). Untuk memenuhi permintaan hasil panen jagung yang meningkat diperlukan panen yang meningkat pula (Grote et al., 2005). Masukan tinggi berupa pupuk $\mathrm{N}$ dan $\mathrm{P}$ anorganik telah menghasilkan efisiensi penggunaan yang rendah dan ketidakseimbangan NPK pada tanah, dan selanjutnya pada pertumbuhan dan hasil tanaman.

Unsur hara $\mathrm{N}$, $\mathrm{P}$, dan $\mathrm{K}$ adalah unsur hara makro yang diperlukan dalam jumlah banyak oleh tanaman sehingga menjadi faktor pembatas pertumbuhan tanaman. Sumber hara N, P dan K dapat berasal dari pelapukan mineral tanah, bahan organik, air irigasi, dan pemupukan. Nitrogen adalah unsur makro primer yang merupakan komponen utama tanaman. Tanaman yang tumbuh harus cukup N untuk membentuk sel-sel baru. Fotosintesis menghasilkan karbohidrat dan $\mathrm{O}_{2}$, namun proses tersebut tidak bisa berlangsung untuk menghasilkan protein dan asam nukleat apabila $\mathrm{N}$ tidak tersedia cukup (Nyakpa, et al., 1988). 
Phospor sering juga disebut sebagai kunci kehidupan karena terlibat langsung hampir pada seluruh proses kehidupan dan merupakan komponen setiap sel hidup. Unsur hara tersebut banyak ditemukan pada biji dan titik tumbuh (Damanik, et al., 2010).

Unsur kalium (K) sangat diperlukan untuk pemeliharaan status kelembaban air, keseimbangan energi dan tekanan turgor sel, osmoregulasi sel tanaman, translokasi fotosintat serta membantu pembukaan dan penutupan stomata (Mengal and Kirkby, 1987; Balasubramian and Palaniappan, 2001; Meille and Pellerin, 2008). Pupuk K berfungsi meningkatkan pertumbuhan dan hasil panen pipilan kering di bawah kondisi stres kelembaban di iklim kering (Fan, et al., 2005).

Lahan kering dataran rendah beriklim kering mempunyai kondisi agroekologi dengan curah hujan rendah sehingga ketersediaan air sangat rendah kurang dari $2.000 \mathrm{~mm} / \mathrm{tahun}$ (Las, et al., 1992) dan mengakibatkan terjadinya evaporasi dan tranpirasi lebih tinggi daripada curah hujan. Jumlah bulan basah pendek (3-5 bulan) sedangkan bulan kering sangat panjang (7-9 bulan) dengan tingkat kesuburan tanah yang rendah (Irianto, et al., 1998). Untuk mengantisipasi terjadinya ketidakseimbangan hara tersebut maka penambahan unsur hara makro N, P, dan $\mathrm{K}$ harus diberikan dalam jumlah yang sesuai dengan kebutuhan tanaman.

Ketersediaan kalium dalam lahan kering iklim kering atau lahan tadah hujan merupakan faktor pembatas utama pertumbuhan dan produksi tanaman karena kemampuanya dalam menjaga ketersediaan air tanah sehingga menekan terjadinya stres air pada tanaman. Tanaman yang terus-menerus stres kekeringan dapat membentuk reactive oxygen spesies (ROS) yang mengarah pada kerusakan daun dan akhirnya mengurangi hasil panen. Selama musim kemarau, pertumbuhan akar dan tingkat difusi $\mathrm{K}^{+}$dalam tanah ke arah akar agak terhambat sehingga membatasi akuisisi K. Konsentrasi K yang dihasilkan lebih rendah akibatnya penyerapan unsur hara lainnya dan ketahanan tanaman terhadap kekeringan tertekan. Oleh karena itu penting untuk tetap menjaga kecukupan tanaman terhadap unsur K. Hubungan erat antara status hara $\mathrm{K}$ dan ketahanan tanaman terhadap kekeringan telah 
dibuktikan oleh Bashir (2012). Sementara itu untuk mencapai keseimbangan hara, pemberian NPK masih perlu ditambah dengan pupuk tunggal, terutama sumber hara N, di antaranya yaitu urea. Menurut Sudriatna, et al. (2006) penambahan 220 kg urea ha ${ }^{-1}$ dengan NPK 16-16-16 225 $\mathrm{kg} \mathrm{ha}^{-1}$ nyata meningkatkan hasil jagung pipilan kering. Oleh karena itu, diperlukan kajian terhadap unsur hara makro Nitrogen, Phospor dan Kalium dan kontribusinya terhadap peningkatan pertumbuhan dan hasil jagung.

\section{METODE}

Waktu dan Tempat Penelitian

Penelitian dilaksanakan di lahan kering dataran rendah iklim kering Kabupaten Pamekasan pada MK-2 tanggal 25 Agustus 2018 dan panen 26 Nopember 2018 dengan umur panen 117 HST (hari setelah tanam).

\section{Bahan dan Alat}

Penelitian menggunakan jagung varietas Hibrida NK 212 dan pupuk NPK 15-10-19. Jagung NK 212 mempunyai warna biji orange cerah, daun lebih lebar daripada varietas lokal serta mempunyai ketahanan terhadap penyakit yang lebih kuat yaitu toleran terhadap bulai, busuk batang dan batangnya lebih kuat dengan potensi hasil mencapai 12,5 ha pipilan kering.

\section{Perancangan Percobaan}

Percobaan menggunakan Rancangan Acak Kelompok dengan tiga ulangan. Perlakuan terdiri dari 10 kombinasi pemupukan termasuk kontrol. Perlakuan percobaan sebagai berikut:

A: tanpa pemupukan (kontrol)

B: $350 \mathrm{kgha}^{-1}$ Urea $+450 \mathrm{kgha}^{-1}$ NPK Phonska (dosis rekomendasi)

C: $250 \mathrm{kgha}^{-1}$ Urea $+250 \mathrm{kgha}^{-1}$ NPK 1510-19

D: $250 \mathrm{kgha}^{-1}$ Urea + $350 \mathrm{kgha}^{-1}$ NPK 1510-19

E: $250 \mathrm{kgha}^{-1}$ Urea $+450 \mathrm{kgha}^{-1}$ NPK $15-$ 10-19

F: $250 \mathrm{kgha}^{-1}$ Urea + $550 \mathrm{kgha}^{-1}$ NPK 15$10-19$

G: $350 \mathrm{kgha}^{-1}$ Urea $+250 \mathrm{kgha}^{-1}$ NPK 1510-19

H: $350 \mathrm{kgha}^{-1}$ Urea $+350 \mathrm{kgha}^{-1}$ NPK $15-10-19$

I: $350 \mathrm{kgha}^{-1}$ Urea + $450 \mathrm{kgha}^{-1}$ NPK $15-$ $10-19$

J: $350 \mathrm{kgha}^{-1}$ Urea $+550 \mathrm{kgha}^{-1}$ NPK 1510-19 
Ukuran masing-masing plot pengujian adalah $6 \mathrm{~m} \times 4 \mathrm{~m}\left(24 \mathrm{~m}^{2}\right)$ dengan jumlah sampel 5 tanaman/plot. yang diambil secara acak.

\section{Pelaksanaan Percobaan}

Lahan dicangkul dan diberi pupuk organik dengan dosis 1 tonha $^{-1}$. Gulma dibersihkan. Selanjutnya dibuat bedengan yang merupakan satuan plot penelitian. Penanaman benih secara tugal dengan. jarak tanam $20 \mathrm{~cm} \times 70 \mathrm{~cm}$ sebanyak 1-2 per lubang tanam.

Pemupukan dilakukan 2 kali yaitu saat tanaman berumur 15 dan 30 HST. Pemupukan diberikan sekitar $5 \mathrm{~cm}$ dari pangkal batang dengan cara larikan. Pengairan dilakukan sesuai dengan kondisi lahan dan tanaman. Pengendalian gulma dilakukan bersamaan dengan pembumbunan secara manual menggunakan sabit saat tanaman berumur 25 dan 45 HST. Pengendalian hama dan penyakit menggunakan pestisida sesuai dengan dosis rekomendasi. Panen dilakukan saat kondisi masak fisiologis, yaitu umur 117 HST.

Pengambilan contoh tanah dilakukan dengan cara komposit di mana contoh tanah diambil secara diagonal dari
5 titik pada kedalaman 0-20 cm. Sampel tanah diuji di Laboratorium Tanah BPTP Jawa Timur. Komponen uji meliputi: kadar air, $\mathrm{pH} \mathrm{H}_{2} \mathrm{O}$ dan $\mathrm{pH} \mathrm{KCl}, \mathrm{C}-$ organik, $\mathrm{N}$ total, $\mathrm{P}_{2} \mathrm{O}_{5}, \mathrm{~K}$-dd (dapat ditukar), kapasitas tukar kation (KTK), nilai tukar kation, dan tekstur tanah untuk persen debu, liat, dan pasir. Pengamatan agronomis pada tanaman jagung meliputi tinggi tanaman pada umur 75 HST, jumlah daun, panjang tongkol, diameter tongkol, bobot 100 biji, dan bobot pipilan kering tonha ${ }^{-1}$. Data pertumbuhan dan hasil jagung dianalisis dengan Uji $\mathrm{F}$ dilanjutkan dengan uji perbandingan nyata DMRT pada $\alpha=5 \%$. Perhitungan ekonomis dilakukan dengan R/C ratio dan $\mathrm{B} / \mathrm{C}$ ratio.

\section{HASIL DAN PEMBAHASAN}

\section{Hasil Analisis Tanah}

Hasil analisis tanah menunjukkan $\mathrm{pH} \mathrm{H}_{2} \mathrm{O}$ netral yaitu 6.90, kandungan $\mathrm{C}$ organik $0.88 \%$ (kriteria rendah), $\mathrm{N}$ Total $0.18 \%$ (kriteria sangat rendah), $\mathrm{P}_{2} \mathrm{O}_{5} 64$ ppm (kiteria sangat tinggi), K-dd0.20 (kriteria rendah) dengan KTK 14,21 me.100g-1 (kriteria rendah) dan tekstur tanah berdasarkan segitiga tekstur USDA 
adalah liat dengan kandungan pasir 35\%, debu 24\%, dan liat $41 \%$ (Tabel 1).

Rendahnya unsur $\mathrm{K}$ dalam tanah karena lokasi penelitian termasuk lahan kering sebagaimana disampaikan oleh Nursyamsi, et al. (2005) di mana kandungan $\mathrm{K}$ di lahan kering pada umumnya rendah. Disamping itu, unsur K mudah terurai dalam tanah dan $\mathrm{K}$ dalam jaringan tanaman banyak terangkut keluar lahan akibat aktivitas panen dan tidak dilakukan usaha pengembalian brangkasan ke lahan. Oleh karena itu penambahan NPK melalui pupuk organik maupun pupuk anorganik diperlukan agar kalium tidak menjadi faktor pembatas bagi penyerapan unsur lainnya (Rauf, et al., 2000) serta untuk tetap memelihara keseimbangan ketersediaan unsur hara.

Tabel 1. Hasil Analisis Tanah di Lokasi Penelitian Pupuk NPK 15-10-19 pada Jagung Kabupaten Pamekasan

\begin{tabular}{|c|c|c|c|c|c|}
\hline No & $\begin{array}{c}\text { Parameter } \\
\text { Uji }\end{array}$ & Hasil & Satuan & Kriteria & Metode \\
\hline 1 & Kadar Air & 4,05 & $\%$ & & Oven $105^{\circ} \mathrm{C}$ \\
\hline \multirow[t]{3}{*}{2} & $\mathrm{pH}$ & & & & \\
\hline & $-\mathrm{H}_{2} \mathrm{O}$ & 6,9 & - & Netral & $\begin{array}{l}\text { (1:5),Elektrometry;p } \\
\text { H Meter }\end{array}$ \\
\hline & $-\mathrm{KCl}$ & 6,1 & - & & $\begin{array}{l}\text { (1:5),Elektrometry;p } \\
\text { H Meter }\end{array}$ \\
\hline 3 & C-Organik*) & 0,88 & $\%$ & Sangat Rendah & $\begin{array}{l}\text { Walkley \& Black; } \\
\text { Spectrophotometry }\end{array}$ \\
\hline 4 & N-total*) & 0,18 & $\%$ & Rendah & Kjeldahl; Titrimetry \\
\hline 5 & $\left.\mathrm{P}_{2} \mathrm{O}_{5} *\right)$ & 64 & Ppm & Sangat Tinggi & $\begin{array}{l}\text { Olsen; } \\
\text { Spectrophotometry }\end{array}$ \\
\hline \multirow[t]{3}{*}{6} & $\begin{array}{l}\text { Nilai Tukar } \\
\text { Kation*) }\end{array}$ & & & & \\
\hline & $\begin{array}{l}\text { - K-dd (dapat } \\
\text { ditukar) }\end{array}$ & 0,20 & me. $100 \mathrm{~g}^{-1}$ & Rendah & $\begin{array}{l}\text { Perkolasi } \mathrm{NH}_{4}{ }^{-} \text {Acetat } \\
1 \mathrm{M}, \mathrm{pH} 7 \text {; AAS }\end{array}$ \\
\hline & $\begin{array}{c}\text { - Kapasitas Tukar } \\
\text { Kation (KTK) }\end{array}$ & 14,21 & me. $100 \mathrm{~g}^{-1}$ & Rendah & $\begin{array}{l}\text { Perkolasi } \mathrm{NH}_{4}{ }^{-} \text {Acetat } \\
1 \mathrm{M}, \mathrm{pH} 7+\mathrm{NaCl} \\
10 \% \text {; Titrimetry }\end{array}$ \\
\hline \multirow[t]{5}{*}{7} & Tekstur*) & & & & \\
\hline & - Pasir & 35 & $\%$ & & Hidrometer \\
\hline & - Debu & 24 & $\%$ & & Hidrometer \\
\hline & - Liat & 41 & $\%$ & & Hidrometer \\
\hline & - Kriteria & Liat & - & & $\begin{array}{l}\text { Segitiga Tekstur } \\
\text { (USDA) }\end{array}$ \\
\hline
\end{tabular}

Sumber: Laboratorium Tanah BPTP Jawa Timur, 2018 
Berdasarkan Tabel 1. kandungan Corganik tanah di lahan penelitian termasuk rendah, yaitu $0.88 \%$, kandungan $\mathrm{N}$ total $0.18 \%$ sangat rendah, K-dd 0.20 rendah dan Kapasitas Tukar Kation (KTK) 14,21 me.100g $\mathrm{g}^{-1}$ rendah. Oleh karena itu saat pelaksanaan penelitian ditambahkan kompos sebanyak 1 tonha ${ }^{-1}$. Menurut Herviyanti, et al. (2012) bahan organik penting dalam meningkatkan kestabilan agregat tanah.

\section{Komponen Pertumbuhan Tanaman}

\section{Tinggi Tanaman}

Hasil analisis ragam menunjukkan bahwa perlakuan pemupukan menunjukkan pengaruh nyata terhadap tinggi tanaman 75 HST (Tabel 2). Pada 75 HST perlakuan F serta perlakuan G, H, $\mathrm{I}$, dan $\mathrm{J}$ dengan urea $350 \mathrm{~kg} \mathrm{ha}^{-1}$ tidak berbeda nyata dengan perlakuan $\mathrm{B}$.

Tabel 2. Pengaruh NPK 15-10-19 terhadap Peubah Tinggi Tanaman pada 75 HST

\begin{tabular}{|c|c|c|c|c|c|}
\hline \multirow[b]{2}{*}{ Perlakuan } & \multicolumn{3}{|c|}{ Dosis dan macam Pupuk } & \multirow{2}{*}{$\begin{array}{l}\text { Tinggi tanaman } \\
75 \mathrm{HST}(\mathrm{cm})\end{array}$} & \multirow{2}{*}{$\begin{array}{c}\text { Jumlah } \\
\text { daun } 75 \\
\text { HST (helai) }\end{array}$} \\
\hline & $\begin{array}{c}\text { Urea } \\
\left(\mathrm{kg} \mathrm{ha}^{-1}\right)\end{array}$ & $\begin{array}{l}\text { NPK Phonska } \\
\quad\left(\mathrm{kg} \mathrm{ha}^{-1}\right)\end{array}$ & $\begin{array}{l}\text { NPK 15-10-19 } \\
\quad\left(\mathrm{kg} \mathrm{ha}^{-1}\right)\end{array}$ & & \\
\hline A & 0 & 0 & 0 & $187.3 \mathrm{~d}$ & $14.60 \mathrm{a}$ \\
\hline $\mathrm{B}$ & 350 & 450 & 0 & $215.00 \mathrm{ab}$ & $15.00 \mathrm{a}$ \\
\hline $\mathrm{C}$ & 250 & 0 & 250 & $196.00 \mathrm{~cd}$ & $14.00 \mathrm{a}$ \\
\hline $\mathrm{D}$ & 250 & 0 & 350 & $201.00 \mathrm{bc}$ & $13.50 \mathrm{a}$ \\
\hline $\mathrm{E}$ & 250 & 0 & 450 & $209.00 \mathrm{bc}$ & $14.00 \mathrm{a}$ \\
\hline $\mathrm{F}$ & 250 & 0 & 550 & $218.00 \mathrm{ab}$ & $15.00 \mathrm{a}$ \\
\hline $\mathrm{G}$ & 350 & 0 & 250 & $220.00 \mathrm{ab}$ & $14.00 \mathrm{a}$ \\
\hline $\mathrm{H}$ & 350 & 0 & 350 & $216.00 \mathrm{ab}$ & $14.10 \mathrm{a}$ \\
\hline $\mathrm{I}$ & 350 & 0 & 450 & $216.00 \mathrm{a}$ & $14.10 \mathrm{a}$ \\
\hline $\mathrm{J}$ & 350 & 0 & 550 & $220.00 \mathrm{a}$ & $14.30 \mathrm{a}$ \\
\hline $\mathrm{KK}(\%)$ & & & & 13.15 & 4.89 \\
\hline
\end{tabular}

Keterangan: Angka yang didampingi oleh huruf yang sama pada setiap kolom menunjukkan tidak berbeda nyata pada DMRT $(\alpha=5 \%)$

\section{Jumlah Daun}

Hasil analisis ragam menunjukkan bahwa perlakuan tidak berpengaruh nyata terhadap jumlah daun pada 75 HST. Hal ini sebagaimana penelitian Saragih, et al.
(2013) bahwa terjadi penambahan tinggi tanaman, tetapi tidak dengan penambahan jumlah ruas batang, melainkan penambahan panjang ruas batang 
sehingga jumlah daun pada semua perlakuan tidak berbeda nyata.

\section{Komponen Hasil Tanaman}

\section{Panjang Tongkol dan Diameter} Tongkol

Hasil analisis ragam menunjukkan terhadap panjang dan diameter tongkol (Tabel 3). Semua perlakuan menghasilkan tongkol yang lebih panjang dan berbeda nyata jika dibandingkan dengan kontrol. Panjang tongkol pada kontrol 13,10 cm dan rata-rata panjang tongkol perlakuan lainnya $16,81 \mathrm{~cm}$.

bahwa perlakuan berpengaruh nyata

Tabel 3. Pengaruh Pupuk NPK 15-10-19 terhadap Peubah Panjang Tongkol, Diameter Tongkol di Kabupaten Pamekasan

\begin{tabular}{|c|c|c|c|c|c|}
\hline \multirow[b]{2}{*}{ Perlakuan } & \multicolumn{3}{|c|}{ Dosis dan Macam Pupuk } & \multirow{2}{*}{$\begin{array}{c}\text { Panjang } \\
\text { tongkol } \\
(\mathrm{cm})\end{array}$} & \multirow{2}{*}{$\begin{array}{c}\text { Diameter } \\
\text { tongkol } \\
(\mathrm{cm})\end{array}$} \\
\hline & $\begin{array}{c}\text { Urea } \\
\left(\text { kgha }^{-1)}\right.\end{array}$ & $\begin{array}{c}\text { NPK Phonska } \\
\left(\text { kgha }^{-1}\right)\end{array}$ & $\begin{array}{c}\text { NPK 15-10-19 } \\
\left(\mathrm{kg} \mathrm{ha}^{-1}\right)\end{array}$ & & \\
\hline A & 0 & 0 & 0 & $13.10 \mathrm{~d}$ & $2.90 \mathrm{~b}$ \\
\hline B & 350 & 450 & 0 & $17.70 \mathrm{a}$ & $3.28 \mathrm{a}$ \\
\hline $\mathrm{C}$ & 250 & 0 & 250 & $16.37 \mathrm{c}$ & $3.13 \mathrm{ab}$ \\
\hline D & 250 & 0 & 350 & $16.40 \mathrm{bc}$ & $3.12 \mathrm{ab}$ \\
\hline $\mathrm{E}$ & 250 & 0 & 450 & $16.80 \mathrm{abc}$ & $3.13 \mathrm{ab}$ \\
\hline $\mathrm{F}$ & 250 & 0 & 550 & $16.93 \mathrm{abc}$ & $3.13 \mathrm{ab}$ \\
\hline G & 350 & 0 & 250 & $17.43 \mathrm{abc}$ & $3.27 \mathrm{ab}$ \\
\hline $\mathrm{H}$ & 350 & 0 & 350 & $14.40 \mathrm{abc}$ & $3.27 \mathrm{a}$ \\
\hline I & 350 & 0 & 450 & $17.50 \mathrm{ab}$ & $3.26 \mathrm{ab}$ \\
\hline $\mathrm{J}$ & 350 & 0 & 550 & $17.73 \mathrm{a}$ & $3.29 \mathrm{a}$ \\
\hline
\end{tabular}

Keterangan: Angka yang didampingi oleh huruf yang sama pada setiap kolom menunjukkan tidak berbeda nyata pada DMRT $(\alpha=5 \%)$

Diameter tongkol pada perlakuan rekomendasi lebih besar dan berbeda nyata jika dibanding dengan kontrol. Diameter tongkol pada kontrol 2,90 cm dan perlakuan rekomendasi diameter tongkol mencapai $3,28 \mathrm{~cm}$. Diameter tongkol pada semua perlakuan tidak berbeda nyata dengan diameter pada perlakuan B. Menurut Bara dan Chozin
(2009), semakin besar diameter tongkol maka hasil per hektar akan semakin meningkat karena biji yang terdapat pada tongkol semakin banyak sehingga bobot biji yang terdapat pada tongkol juga semakin besar dan meningkatkan hasil panen. 


\section{Bobot 100 Biji dan Bobot Pipilan Kering Biji Jagung}

Hasil analisis ragam menunjukkan pengaruh nyata perlakuan terhadap peubah bobot 100 biji jagung dan bobot jagung pipilan kering (Tabel 4). Bobot biji semua perlakuan tidak berbeda nyata dengan perlakuan B yang berarti bahwa semua dosis perlakuan pupuk NPK 1510-19 menghasilkan bobot biji yang secara statistik sama dengan perlakuan rekomendasi.

Tabel 4. Pengaruh Pupuk NPK 15-10-19 terhadap Bobot 100 Butir dan Pipilan Kering Jagung di Kabupaten Pamekasan

\begin{tabular}{|c|c|c|c|c|c|}
\hline \multirow[b]{2}{*}{ Perlakuan } & \multicolumn{3}{|c|}{ Dosis dan Macam Pupuk } & \multirow{2}{*}{$\begin{array}{c}\text { Bobot } 100 \\
\text { biji } \\
\text { (gram) }\end{array}$} & \multirow{2}{*}{$\begin{array}{c}\text { Bobot pipilan } \\
\text { kering } \\
\left(\text { tonha }^{-1}\right)\end{array}$} \\
\hline & $\begin{array}{c}\text { Urea } \\
\left(\mathrm{kgha}^{-1}\right)\end{array}$ & $\begin{array}{c}\text { NPK Phonska } \\
\left(\mathrm{kgha}^{-1}\right)\end{array}$ & $\begin{array}{c}\text { NPK 15-10-19 } \\
\quad\left(\mathrm{kg} \mathrm{ha}^{-1}\right)\end{array}$ & & \\
\hline A & 0 & 0 & 0 & $24.30 \mathrm{~b}$ & $5.10 \mathrm{e}$ \\
\hline B & 350 & 450 & 0 & $27.90 \mathrm{a}$ & $8.05 \mathrm{a}$ \\
\hline $\mathrm{C}$ & 250 & 0 & 250 & $26.60 \mathrm{ab}$ & $5.60 \mathrm{de}$ \\
\hline $\mathrm{D}$ & 250 & 0 & 350 & $26.97 \mathrm{a}$ & $6.20 \mathrm{~cd}$ \\
\hline $\mathrm{E}$ & 250 & 0 & 450 & $27.03 \mathrm{a}$ & $6.90 \mathrm{bc}$ \\
\hline $\mathrm{F}$ & 250 & 0 & 550 & $27.17 \mathrm{a}$ & $6.95 \mathrm{abc}$ \\
\hline G & 350 & 0 & 250 & $27.27 \mathrm{a}$ & $7.30 \mathrm{ab}$ \\
\hline $\mathrm{H}$ & 350 & 0 & 350 & $27.20 \mathrm{a}$ & $7.45 \mathrm{ab}$ \\
\hline $\mathrm{I}$ & 350 & 0 & 450 & $27.37 \mathrm{a}$ & $7.95 \mathrm{ab}$ \\
\hline $\mathrm{J}$ & 350 & 0 & 550 & $28.30 \mathrm{a}$ & $7.98 \mathrm{ab}$ \\
\hline $\mathrm{KK}(\%)$ & & & & 5.23 & 7.51 \\
\hline
\end{tabular}

Keterangan: Angka yang didampingi oleh huruf yang sama pada setiap kolom menunjukkan tidak berbeda nyata pada DMRT $(\alpha=5 \%)$

Pemberian unsur $\mathrm{N}$ atau Urea sangat penting mengingat perannya dalam pertumbuhan vegetatif awal tanaman jagung. Menurut Suwardi dan Roy (2009), pemberian $\mathrm{N}$ yang semakin tinggi berpengaruh terhadap tinggi tanaman dan bobot kering tanaman. Dari hasil penelitian dapat diketahui bahwa penambahan pupuk $\mathrm{N}$ tunggal diperlukan untuk memenuhi kebutuhan hara tanaman jagung untuk pertumbuhan dan hasil yang optimal meskipun sudah diberikan pupuk NPK 15-10-19. Shilpashree, et al. (2012) mengatakan bahwa pemupukan $\mathrm{N}$ nyata meningkatkan pertumbuhan dan bobot biji jagung. Penelitian Aluwi, et al. (2012) dan Tabri (2010) menunjukkan bahwa hasil jagung rendah jika tidak ditambahkan pupuk $\mathrm{N}$. 
Penambahan pupuk NPK dari 250 menjadi $350 \mathrm{~kg} \mathrm{ha}^{-1}$ terbukti tidak mampu mampu menghasilkan bobot pipilan kering yang berbeda nyata dengan perlakuan rekomendasi atau perlakuan B. Sutoro, et al. (1998) menyatakan bahwa kalium dibutuhkan tanaman jagung dalam jumlah paling banyak dibandingkan dengan hara $\mathrm{N}$ dan $\mathrm{P}$. Akumulasi $\mathrm{K}$ mencapai $60-75 \%$ dari seluruh kebutuhan saat fase pembungaan. Kekurangan $\mathrm{K}$ berpengaruh terhadap pembentukan tongkol dan biji jagung. Pemberian kalium memberikan peningkatan hasil jagung secara nyata dibandingkan dengan tanpa pemberian K. Hasil penelitian Ahmad, et al. (2017) juga memberikan informasi bahwa penggunaan pupuk $\mathrm{K}$ meningkatkan pertumbuhan tanaman dan panen melalui penambahan jumlah dan ukuran biji jagung.

Pada perlakuan $\mathrm{G}, \mathrm{H}$, I, dan $\mathrm{J}$ pemakaian dosis urea $350 \mathrm{~kg} \mathrm{ha}^{-1}$ ditambah dengan dosis pupuk NPK 1510-19 yang semakin meningkat dari 250, 350 450, sampai $550 \mathrm{~kg} \mathrm{ha}^{-1}$ tidak meningkatkan bobot pipilan kering biji jagung secara signifikan.

\section{Analisis Finansial}

Analisis finansial usahatani jagung perlakuan pupuk NPK 15-10-19 dapat dilihat pada Tabel 5, 6, dan 7 .

Tabel 5. Analisis Finansial Pupuk NPK 15-10-19 pada Jagung di Kabupaten Pamekasan

\begin{tabular}{ccccc}
\hline Perlakuan & $\begin{array}{c}\text { Jenis dan Dosis Pupuk } \\
\left(\mathrm{kgha}^{-1}\right)\end{array}$ & $\begin{array}{c}\text { Biaya Pupuk } \\
(\mathrm{Rp})\end{array}$ & $\begin{array}{c}\text { Produksi jagung } \\
\text { pipilan kering } \\
\left(\text { tonha }^{-1}\right)\end{array}$ & R/C \\
\hline A & 0 & 0 & 5.10 & - \\
B & 450 Urea + 300 Phonska & 1.597 .500 & 8.05 & 2.15 \\
C & 250Urea + 250 NPK 15-10-19 & 1.880 .000 & 5.60 & - \\
D & 250 Urea + 350 NPK 15-10-19 & 2.452 .000 & 6.20 & - \\
E & 250 Urea + 450 NPK 15-10-19 & 3.024 .000 & 6.90 & 1.85 \\
F & 250 Urea + 550 NPK 15-10-19 & 3.596 .000 & 6.95 & 1.79 \\
G & 350 Urea + 250 NPK 15-10-19 & 2.060 .000 & 7.30 & 2.14 \\
H & 350 Urea + 350 NPK 15-10-19 & 2.632 .000 & 7.45 & 2.05 \\
I & 350 Urea + 450 NPK 15-10-19 & 3.204 .000 & 7.95 & 2.00 \\
J & 350 Urea + 550 NPK 15-10-19 & 3.776 .000 & 7.98 & 2.03 \\
\hline
\end{tabular}

Keterangan : Harga Pupuk 15-10-19=Rp 5.720 ; NPK Phonska= Rp 2.350; Urea= Rp 1.800; Pupuk organik= Rp. 500 per kg. 
Analisis finansial menunjukkan bahwa biaya input produksi untuk pupuk pada perlakuan B paling rendah yaitu Rp 1.597.500. Dibandingkan dengan semua perlakuan pemupukan lainnya, biaya input produksi perlakuan dosis rekomendasi tersebut yang paling rendah. Hal tersebut antara lain disebabkan adanya selisih Harga Eceran Tertinggi (HET) $\mathrm{kg}^{-1}$ antara NPK Phonska dengan NPK 15-10-19 yaitu sebesar Rp 5.720-Rp 2.350= Rp $3.370 \mathrm{~kg}^{-1}$. Biaya pupuk yang tertinggi pada perlakuan $\mathrm{J}\left(350 \mathrm{kgha}^{-1} \mathrm{Urea}+550 \mathrm{~kg} \mathrm{ha}^{-1} \mathrm{NPK}\right.$ 15-10-19) sebesar Rp 3.776.000,--.

Sebagaimana dijelaskan sebelumnya pada peubah bobot pipilan kering, bahwa pada perlakuan G,H,I, danJ pemakaian dosis urea $350 \mathrm{~kg} \mathrm{ha}^{-1}$ ditambah dengan dosis pupuk NPK 15-10-19 yang semakin meningkat dari 250, 350, 450, sampai $550 \mathrm{~kg} \mathrm{ha}^{-1}$ tidak meningkatkan bobot pipilan kering biji jagung secara signifikan sehingga disarankan pemupukan NPK 15-10-19 di lahan kering dataran rendah iklim kering adalah dosis yang terendah diantara perlakuan G,H,I, danJ. Dosis terendah adalah perlakuan G dan didukung juga dengan hasil analisis finansial yang tidak jauh berbeda dengan keuntungan yang dihasilkan dengan aplikasi perlakuan B dosis rekomendasi. R/C ratio perlakuan Gsebesar 2,14 dan perlakuan B dosis rekomendasi $\mathrm{R} / \mathrm{C}$ ratio sebesar 2,15.

Tabel 6. Analisis ekonomi sederhana pengaruh penggunaan pupuk NPK 15-10-19 pada tanaman jagung di Kabupaten Pamekasan, 2018

\begin{tabular}{cccccrr}
\hline \multirow{2}{*}{ Perlakuan } & $\begin{array}{c}\text { Produksi } \\
\left(\text { tha }^{-1}\right)\end{array}$ & $\begin{array}{c}\text { Pupuk } \\
(\mathrm{Rp})\end{array}$ & $\begin{array}{c}\text { Non Pupuk } \\
(\mathrm{Rp})\end{array}$ & $\begin{array}{c}\text { Harga } \\
\text { Jual/kg } \\
(\mathrm{Rp})\end{array}$ & $\begin{array}{c}\text { Nilai Jual } \\
(\mathrm{Rp})\end{array}$ & $\begin{array}{r}\text { Pendapatan } \\
(\mathrm{Rp})\end{array}$ \\
\hline A & 5.10 & 0 & 12.615 .000 & 3.750 & 19.125 .000 & 7.560 .000 \\
B & 8.05 & 1.597 .500 & 12.615 .000 & 3.750 & 28.690 .000 & 15.342 .500 \\
C & 5.60 & 1.880 .000 & 12.615 .000 & 3.750 & 21.280 .000 & 8.240 .000 \\
D & 6.20 & 2.452 .000 & 12.615 .000 & 3.750 & 23.560 .000 & 9.956 .000 \\
E & 6.90 & 3.024 .000 & 12.615 .000 & 3.750 & 26.220 .000 & 12.052 .000 \\
F & 6.95 & 3.596 .000 & 12.615 .000 & 3.750 & 26.410 .000 & 11.634 .000 \\
G & 7.30 & 2.060 .000 & 12.615 .000 & 3.750 & 28.310 .000 & 15.090 .000 \\
H & 7.45 & 2.632 .000 & 12.615 .000 & 3.750 & 28.310 .000 & 14.526 .000 \\
I & 7.95 & 3.204 .000 & 12.615 .000 & 3.750 & 28.690 .000 & 14.342 .000 \\
J & 7.98 & 3.776 .000 & 12.615 .000 & 3.750 & 30.324 .000 & 15.368 .000 \\
\hline
\end{tabular}

Keterangan : Biaya non pupuk : tenaga kerja, benih, pestisida, sewa lahan, dan iuran pengairan atau HIPPA. Harga jual jagung pipilan kering saat panen Rp 3.750 per kg; harga Urea Rp 1.800, NPK Phonska Rp 2.350; Pupuk NPK 15-10-19 Rp 5.720,- 
Pada Tabel 6 diketahui bahwa kontrol memberikan pendapatan usahatani yang paling rendah yaitu $\mathrm{Rp}$
7.560.000,- dan tertinggi pada perlakuan J yaitu sebesar Rp 15.368.000,--

Tabel 7. Analisis Finansial Usahatani Padi Perlakuan Pupuk NPK 15-10-19 pada Perlakuan G Dibandingkan dengan Perlakuan B Pupuk Rekomendasi di Kabupaten Pamekasan

\begin{tabular}{|c|c|c|c|c|c|}
\hline Uraian & Jumlah & Satuan & Biaya & $\begin{array}{l}\text { Perlakuan } \\
\text { Pupuk } \\
\text { Rekomendasi }\end{array}$ & Perlakuan G \\
\hline \multicolumn{6}{|l|}{ Biaya Sarana Produksi : } \\
\hline Benih jagung & 15 & $\mathrm{Kg}$ & 75.000 & 1.125 .000 & 1.125 .000 \\
\hline NPK 15-10-19 & & $\mathrm{Kg}$ & 5.720 & 0 & 1.410 .000 \\
\hline NPK Phonska & & $\mathrm{Kg}$ & 2.350 & 1.057 .500 & 0 \\
\hline Urea & & $\mathrm{Kg}$ & 1.800 & 540.000 & 630.000 \\
\hline Petroganik & 500 & $\mathrm{Kg}$ & 500 & 250.000 & 250.000 \\
\hline Pestida & 2 & $\mathrm{Lt}$ & 150.000 & 300.000 & 300.000 \\
\hline \multicolumn{6}{|l|}{ Biaya Tenaga Kerja: } \\
\hline Pengolahan lahan & 18 & HOK & 70.000 & 1.260 .000 & 1.260 .000 \\
\hline Perbaikan parit & 7 & $\mathrm{HOK}$ & 70.000 & 490.000 & 490.000 \\
\hline $\begin{array}{l}\text { Meratan tanah/membuat } \\
\text { bedengan }\end{array}$ & 12 & $\mathrm{HOK}$ & 70.000 & 840.000 & 840.000 \\
\hline Penanaman & 10 & $\mathrm{HOK}$ & 50.000 & 500.000 & 500.000 \\
\hline Pemupukan & 15 & HOK & 70.000 & 1.050 .000 & 1.050 .000 \\
\hline Penyiangan & 20 & HOK & 70.000 & 1.400 .000 & 1.400 .000 \\
\hline $\begin{array}{l}\text { Pengendalian Organisme } \\
\text { Pengganggu Tanaman }\end{array}$ & 5 & HOK & 70.000 & 350.000 & 350.000 \\
\hline Pengairan & 10 & HOK & 50.000 & 500.000 & 500.000 \\
\hline Panen dan pengangkutan & 20 & $\mathrm{HOK}$ & 70.000 & 1.400 .000 & 1.400 .000 \\
\hline $\begin{array}{l}\text { Pengeringan dan } \\
\text { perontokan } \\
\text { Biaya lain-Lain }\end{array}$ & 20 & HOK & 70.000 & 1.400 .000 & 1.400 .000 \\
\hline Sewa Lahan & $1 \mathrm{MT}$ & & & 1.500 .000 & 1.500 .000 \\
\hline Iuran HIPPA/pengairan & $1 \mathrm{MT}$ & & & 200.000 & 200.000 \\
\hline Total Biaya & & & & 11.565 .000 & 13.220 .000 \\
\hline Produksi $\left(\mathrm{kgha}^{-1}\right)$ & & & & 7.550 & 7.450 \\
\hline Nilai Produksi & & & & 28.690 .000 & 28.310 .000 \\
\hline Pendapatan & & & & 8.240 .000 & 15.090 .000 \\
\hline R/C Ratio & & & & 2.15 & 2.14 \\
\hline
\end{tabular}

Keterangan: HOK= Hari Ongkos Kerja; MT= Musim Tanam 


\section{KESIMPULAN DAN SARAN}

\section{Kesimpulan}

Perlakuan pemupukan NPK 15-1019 berpengaruh nyata terhadap tinggi tanaman, panjang dan diameter tongkol, bobot 100 butir dan hasil jagung pipilan kering. Perlakuan $\mathrm{G}$ dengan aplikasi pupuk $350 \mathrm{kgha}^{-1}$ Urea $+250 \mathrm{kgha}^{-1} \mathrm{NPK}$ 15-10-19 memberikan nilai $\mathrm{R} / \mathrm{C}$ ratio yang lebih tinggi daripada perlakuan lainnya yaitu sebesar 2.14. Aplikasi pupuk NPK dengan kandungan $\mathrm{K}$ tinggi yaitu NPK 15-10-19 sebanyak $250 \mathrm{~kg} \mathrm{ha}^{-1}$ + urea $350 \mathrm{kgha}^{-1}$ merupakan usahatani yang paling menguntungkan dan mampu meningkatkan hasil jagung pipilan kering hingga $7.3 \mathrm{t} \mathrm{ha}^{-1}$ di dataran rendah lahan kering iklim kering.

\section{Saran}

Perlu dilakukan penelitian dengan topik sama tetapi menggunakan pupuk tunggal Nitrogen, pupuk tunggal yang mengandung phosphor dan pupuk tunggal yang kalium.

\section{UCAPAN TERIMA KASIH}

Ucapan terima kasih disampaikan pada Prof. Dr. Suyamto H., MS. sehingga penelitian terlaksana dengan baik, Ir. Handoko M.Sc , dan Ir. Zainal Arifin MP yang mendukung jalannya penelitian. Bapak Imam dan tim sebagai petani yang membantu kegiatan penelitian, dan pihakpihak yang tidak bisa disebutkan satu persatu.

\section{DAFTAR PUSTAKA}

Ahmad. I and M. Akram. 2017. AgroEconomic of Potassium Application in Spring Maize under Early and Late Sown Conditions. Bangladesh J. Sci. Ind.Res. 52(4): 295-302.

Aluwi. F. , F.R Nurdin dan S. F. Jamin. 2012. Hasil Tanaman Jagung yang Dipupuk N, P, Dan K Di Dutohe, Kabupaten Bone Bolango. JATT . 1(2): 81-88.

Balasubramian. P and S.P. Palaniappan. 2001. Principle and Practices of Agronomy. Agrobios (India). Johdpur. India. pp 21-24.

Bara dan Chozin. 2009. Pengaruh Dosis Pupuk Kandang dan Frekuensi Pemberian Pupuk Urea terhadap Pertumbuhan dan Produksi Jagung (Zea mays. L) di Lahan Kering. Makalah Seminar Departemen Agronomi dan Hortikultura. Fakultas Pertanian, Institut Pertanian Bogor. Bogor. 
Bashir. S. 2012. Response of Brown Sarson to NPK Application Under Early, Normal and Late Sown Conditions [Ph.D. Thesis], Division Of Agronomy,SKUASTK.

Damanik. M. M. B., B. E. Hasibuan, Fauzi, Sarifuddin dan H. Hanum. 2010. Kesuburan Tanah dan Pemupukan. Universitas Sumatera Utara. Medan.

Fan. T. L., B.A Stewart, W.A. Payne, Y. Wang, J.J. Luo, Y.F. Gao. 2005. Long-Term Fertilizer and Water Availability Effects on Cereal Yield and Soil Chemical Properties in Northwest China. Soil Sci. Soc. Am. J. 69: 421-428.

Grote. U., E. Craswell, and P. Vlek. 2005. Nutrient Flows in International Trade: Ecology and Policy Issues. Environ. Sci. Policy. 8: 439-451.

Herviyanti, F. Achmad, R. Sofyani, G. Darmawan, A. Saidi. 2012. Pengaruh Pemberian Bahan Humat dari Ekstrak Batu Bara Muda (Subbituminus) dan Pupuk $P$ terhadap Sifat Kimia Ultisol serta Produksi Tanaman Jagung (Zea mays L.). J. Solum. 9(1):1524.

Irianto. G., H. Sosiawan dan S. Karama. 1998. Strategi Pembangunan Pertanian Lahan Kering Untuk Mengantisipasi Persaingan Global. P 1-12. Prosiding Pertemuan Pembahasan Dan Komunikasi Hasil Penelitian Tanah dan Agroklimat. Bogor. 1012 Februari 1998. Puslittanak. Bogor.
Las. I., A.K. Makarim, A. Hidayat, A.S. Karama, dan I. Manwan. 1992. Peta Agroekologi Utama Tanaman Pangan di Indonesia. Puslitbang Tanaman Pangan. Bogor.

Meille L. J and S. Pellerrin. 2008. Shoot and Root Growth of Hydroponic Maize as Influenced by $\mathrm{K}$ Deficiency. J. Plant Soil. 304: 157-168.

Mengal. K and E.A. Kirkby. 1987. Principle of plant Nutrition, 4th Ed., International Potash Institure, Bern, Switzerland. pp 434-440.

Nursyamsi. D, S. Agus, J.S. Adiningsih. 2005. Lahan Sawah dan Pengelolaannya. p 165-196. Sumber Daya Lahan Indonesia dan Pengelolaannya. Pusat Penelitian Tanah dan Agroklimatologi. Bogor.

Nyakpa. M. Y. A., M. Lubis, M. A Pulung, G. Amrah, A. Munawar, G.B. Hong dan N.Hakim 1988. Kesuburan Tanah. Universitas Lampung Press. Lampung.

Rauf. A., W. Syamsuddin, dan S.R. Sihombing. 2000. Peranan Pupuk NPK pada Tanaman Padi. Departemen Pertanian. Badan Penelitian dan Pengembangan Pertanian Loka Pengkajian Teknologi Pertanian Koya BaratIrian Jaya. Jayapura.

Saragih, D., H. Hamim dan N. Nurmauli. 2013. Pengaruh Dosis dan Waktu Aplikasi Pupuk Urea dalam Meningkatkan Pertumbuhan dan Hasil Jagung (Zea mays, L.) 
Pioneer 27. J. Agrotek Tropika. (1): 50-54.

Shilpashree. V.M., H.M. Chidanandappa, R. Jayaprakash, and B.C. Punitha. 2012. Effect of Integrated Nutrient Management Practices on Distribution of Nitrogen Fractions by Maize Crop in Soil. Indian J. of Fundamental and Applied Life Sciences. 1: 38-44.

Sudriatna. U., D. Setyorini, dan A. Hasanudin. 2006. Efektivitas Pupuk Majemuk NPK 16-16-16 pada Tanah Ultisol dan Inceptisol terhadap Pertumbuhan dan Hasil Jagung. Prosiding Seminar Nasional Sumberdaya Lahan Pertanian. Bogor, 14-15 September $2006 . \quad$ p. $97-$ 110.

Sutoro, Y., S dan Iskandar. 1988. Budidaya Tanaman Jagung. Balai Penelitian Tanaman Pangan. Bogor.

Suwardi dan R. Efendi. 2009. Efisiensi Penggunaan Pupuk N pada Jagung Komposit Menggunakan Bagan Warna Daun. Balai Penelitian Tanaman Serelia. Maros.

Tabri. F. 2010. Pengaruh Pupuk N, P, K terhadap Pertumbuhan dan Hasil Jagung Hibrida dan Komposit pada Tanah Inceptisol Kabupaten Barru, Sulawesi Selatan. Prosiding Pekan Serealia Nasional. p 248253.

Tandisau. P dan M. Thamrin. 2016. Kajian Pemupukan N, P, dan K terhadap Jagung (Zea mays Linn.) pada Lahan Kering Tanah Typic Ustropepts. E-jurnal.Litbang Pertanian.Go.Id/Index.Php/Jpengk ajian/ Article/ Download suppfile/ .../77. Tanggal Akses 16 Desember 2018. 